\title{
Facebooking Airspace: A Study on the Effectiveness of Cebu Pacific Facebook Page in Maintaining the Positive Image
}

\author{
Normee Claire Noelle Agatep, Zyra Shemitha Quierrez, and Rowena Capulong-Reyes
}

\begin{abstract}
The emergence of social media is undeniable. With the amount of people going online for faster communication, certain things go viral on the internet in just a short span of time. These things may either make or break a reputation of person or an organization. Cebu Pacific Air, Philippine's leading airline, encountered a lot of incidents resulting to cancellation and delayed of flights. The aim of the study is to determine how Facebook helps in maintaining the public image of Cebu Pacific amidst the negative comments of unsatisfied customers regarding delayed and cancelled flights. Descriptive-Quantitative method was utilized using KAP questionnaire. Four factors emerged: content, communication behavior, crisis response and consistency that could help Cebu Pacific improve their image in the Social Media world. The paper reveals that the content of Cebu Pacific's Facebook page helps the most in maintaining a positive image for the airlines.
\end{abstract}

Index Terms-Social media, facebook, airlines, public image, reputation.

\section{INTRODUCTION}

Air travelers know the frustration of waiting endlessly for their plane to arrive or depart. Delayed flights are inevitable instance that maybe caused by a couple of factors i.e., technical problems, bad weather and air traffic. Although passengers anticipate delays, no one counts on such eventuality to happen to him. On June 2, 2013, a carrier of Cebu Pacific Air had an emergency landing at the Davao International Airport claiming pilot error, and with this single incident, many flights were delayed as a consequence. Using the power of the social media, countless complaints have been voiced out by unsatisfied customers stating their experiences with the airline (Hua [1], 2013). Two weeks after the incident, Cebu Pacific flight 5J448 from Iloilo skidded at the runway as it landed at NAIA during heavy rain, even though no one was harmed, it damaged five head lights of the runway. (Santos [2], 2013) In the month of August, there were also cancellation of flights because of the Typhoon Maring.

These unfortunate incidents proved detrimental to Cebu Pacific Air and its positive image as the low flight leader. As a result, no less than Lance Y. Gokongwei, Cebu Air Inc., president claimed, the airline will miss their target of 15 million passengers for 2013. (Amojelar [3], 2013) Cebu Pacific, the Philippine's number 1 and one of the fastest

Manuscript received October 4, 2013; revised December 3, 2013

Normee Claire Noelle Agatep, Zyra Shemitha Quierrez, and Rowena Capulong-Reyes are with the Colegio de San Juan de Letran (e-mail: mee.agatep@yahoo.com). growing airlines in Asia, is known for having the lowest flight fares with its "low fare everyday promo", but even with a strong foothold as a budget airline, it could not escape the trouble caused by delayed flights or even cancellations. The unforeseen flight delays will eventually bring financial loss and damage to its reputation.

Thus, this paper puts forward the significance of determining whether Cebu Pacific's Facebook Fan Page helps in maintaining the image of Cebu Pacific Air Company. The connection of social media, specifically, Facebook and the maintained positive reputation of Cebu Pacific lead the proponents to further investigate the effectiveness of Facebook in maintaining the image of the said airline despite the cancellations and delays of flights.

\section{METhODOLOGY}

The Cebu Pacific Facebook Fan Page has a total "like" population of approximately one-million-seventy thousand. The researchers profiled the respondents by securing their email addresses, gender, and age. It utilized the descriptive quantitative research method, using probability sampling. The survey form, divided into three parts, used the knowledge, attitude, and practice as a formula. With a population of 120 respondents, the respondents are registered frequent flyers of Cebu Pacific Air, who have experienced delayed and cancelled flights and have liked the official Facebook Fan Page of Cebu Pacific. Data gathering ran for three weeks, from August 14 to August 30. The clients' perception towards the airlines in relation to Cebu Pacific's official Facebook Fan page was categorized, with the most common variables falling under three factors: Content, Communication Behavior, and Crisis Response. The data collected from the frequent fliers were encoded using computer software IBM $\odot$ SPSS $\odot$ Statistics Version 20 in order to compute for the mean, median, and standard deviation of the data.

\section{RESULTS}

\section{A. Delayed Flights}

In the context of Air Transport Industry, different kinds of crises can arise. Crisis is a non-routine event that risk undesired visibility that in turn threatens significant reputational damage (Doorley and Garcia [4], 2010). According to \{Serusi [5], 2012\} there are three common characteristics in which crisis in the air transport industry are mutually evident. "[3] There is no prior notice or 
warning signs, [6] the need to inform large numbers of people in a very short time and [7] a large number of (increasingly digital) angry/distressed people." (Serusi [5], 2012).

Whatever crisis it maybe, whether it is caused by environment or some other factors like air traffic, operation requirements and maintenance, a crisis is still a crisis and it is the reputation that is at stake when crisis enters into the picture. It has been said that "reputations are widely recognized as valuable, intangible asset." (Coombs [8], 2007; Carneli and Tishler [9], 2005)

Data gathered from Cebu Pacific frequent fliers reveal that delayed flights have an effect to the image of the airline. However, Christian Domingo, digital marketing manager of Cebu Pacific Air, counters this claims since delays are foremost caused by outside forces (air traffic, bad weather, and technical problems) that Cebu Pacific has no complete control over. Although Domingo admitted Cebu Pacific considers the June 2, 2013 as a major crisis which may greatly affect their operations.

Contradicting results reveal that while the frequent fliers' perception towards Cebu Pacific's Official Facebook Fan Page has a "negative" perception towards airlines, the respondents still agreed that they will still fly Cebu Pacific even after experiencing delayed flights. The results of this study have been divided into three important factors that greatly contribute to the positive image of Cebu Pacific Fan Page to their clients: Content, Communication Behavior, and Crisis Response.

\section{B. Content}

The content of Cebu Pacific's Official Facebook Fan Page was regarded as a contributor to the positive image of the airline because the fan page carries everything including photos and videos, applications tabs and other features which encourage engagement.

TABLE I: CONTENTS DIVERT THE ATTENTION FOR THE UNANSWERED QUERIES ABOUT DELAYED AND CANCELLED FLIGHTS

\begin{tabular}{|c|c|c|}
\hline 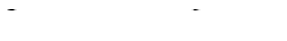 & Frequency & Percentage \\
\hline Low Flight Fares & 64 & 21 \\
\hline Promos & 55 & 18 \\
\hline Updates & 41 & 13 \\
\hline Information & 34 & 11 \\
\hline Queries & 25 & 08 \\
\hline \multicolumn{3}{|c|}{$\begin{array}{l}\text { Content gives a positive impact on } \\
\text { Cebu Pacific's Reput ation }\end{array}$} \\
\hline $\begin{array}{l}\text { Yes } \\
\text { No }\end{array}$ & 98 & $\begin{array}{l}82 \\
18\end{array}$ \\
\hline No & 22 & 18 \\
\hline \multicolumn{3}{|c|}{ Contents that helps maintain the reputation } \\
\hline $\begin{array}{l}\text { Of Cebu Pacific Air } \\
\text { Low Flight Fares }\end{array}$ & 88 & \\
\hline Promos & 67 & 15 \\
\hline Information & 64 & 14 \\
\hline Updates & 56 & 12 \\
\hline Contest, Prizes, Winners & 35 & 08 \\
\hline \multicolumn{3}{|c|}{$\begin{array}{l}\text { Colors and Posters maintain } \\
\text { Positive vibe }\end{array}$} \\
\hline & 110 & 92 \\
\hline No & 10 & 08 \\
\hline \multicolumn{3}{|l|}{$\begin{array}{l}\text { Characteristic of Cebu } \\
\text { Pacific FB Fan Page }\end{array}$} \\
\hline Interesting & 76 & 32 \\
\hline Significant & 56 & 24 \\
\hline Timely & 33 & 14 \\
\hline Relevant & 46 & 20 \\
\hline Truthful & 17 & 07 \\
\hline Other & 06 & 03 \\
\hline
\end{tabular}

The content of Cebu Pacific's Facebook Fan page is one of the things that helps the company maintain its reputation. This is because the clients find these contents interesting and significant. The colors and the posters give them positive vibes as well and that also reflect on the image of
Cebu Pacific. This supports Parkinson, 2007 "Graphics quickly affect the emotions especially in decision making", thus diverting their attention from the unanswered queries to these interesting contents. Among these contents that divert their attention from the negative ones to the positive ones are the Low Flight Fares and other promos of the airlines that are being promoted on the Facebook fan page.

\section{Communication Behavior}

Communication behavior was added as one of the important factors on Cebu Pacific's Facebook page. This covers the Cebu Pacific's performance when it comes to responding to their clients' queries and concerns like how fast they reply and how helpful their replies are to their current plight.

The frequent fliers claimed to have a hard time communicating with Cebu Pacific. This is due to the late and unclear responses. The top two communication problems encountered by the frequent fliers are (1) Late replies and (2) Ignored Questions. People expect feedback to be faster on the internet. Consumers get annoyed when companies have a slow response time on the social media. It annoys them if they don't get a fast response from a company or brand they have contacted via social media channel. (Havas Worldwide [10]' 2013). On the contrary, Cebu Pacific responded that slow responses is due to the fact that the company does not have enough outsourced employees to handle and take action to the online queries of their clients all at the same time. Furthermore, these unanswered queries, would require them to ask the frequent fliers to disclose some personal information on a public site and that cannot be since their clients' privacy is one of their top priorities.

On one hand, the good communication behavior aspects that Cebu Pacific has attained are (1) transparency (2) honesty (3) helpful and (4) good communication relationship. In contrast, the aspects that Cebu Pacific has to improve on are (1) efficiency, (2) dissemination of information, (3) updates (4) quick responses, (5) clarity and (6) timeliness. In addition, electronic replies have also been observed as a factor that does not solve the queries of the clients because it leaves no clarity in their response.

Since Cebu Pacific was not able to fulfill their duty to respond to their clients' concerns and queries on their Facebook fan page in just a short span of time, they were not able to build an efficient rapport between them and their frequent fliers since $54 \%$ of them verified that they have hard time communicating with Cebu Pacific Air and among their reasons are late replies and ignoring questions. Therefore, it can be said that if Cebu Pacific has successfully fulfilled their part in replying to customers as quickly as possible, there would be an efficient rapport built connecting them and their clients. Thus, this affirms that quick and concrete responses to queries on Facebook help in building an efficient rapport between Cebu Pacific Air and their clients.

\section{Crisis Response}

The rapport between the airline and the clients is essential in times of crisis. Customer positive experience is still a plus for the clients in times of crisis. Cebu Pacific delivers (1) updates and (2) sufficient information during and after the crisis thus making the page reliable for clients. This is the age of real-time marketing. It's all about responding and 
reacting to events as quickly as possible. (Bodenlos [6], 2013, Weismann, 2013) Although Cebu Pacific's responses don't come as quickly as they should, the clients still deem it positive in favor of the airline as long as their posts have been responded to, thus, giving back their trust to Cebu Pacific even after a bad experience.

Apologizing to the public is also a plus factor for the airline because apologies are becoming a corner stone of customer satisfaction, trust, loyalty and retention. Customers just seek for an explanation, assurance, apology or even a chance to vent. (Stamato [11], 2008) However, even with the sincerest apologies from the airlines, the clients are still not satisfied with the way Cebu Pacific responds to them due to the slow response time.

TABLE II: CEBU PACIFIC's CRISIS RESPONSE

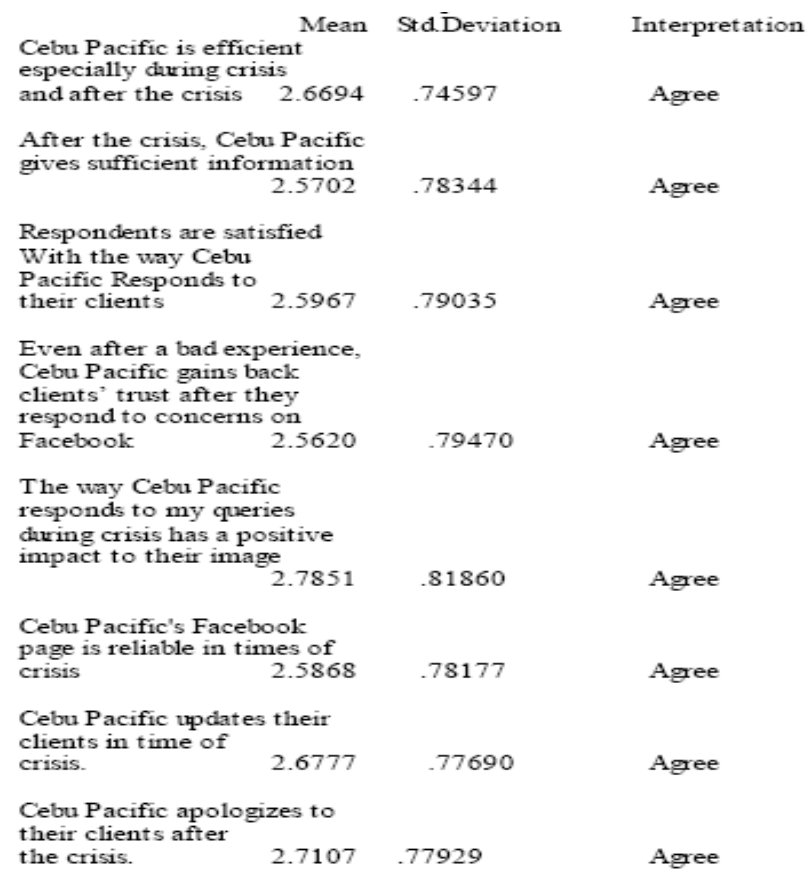

\section{E. Framing in Organizations Theory}

Framing in Organizations theory is used to support this study where in the communication source, such as a news organization, defines and constructs an issue or controversy. (Nelson, Oxley, \& Clawson [12], 1997) In the case of Cebu Pacific, they have been framing these issues by [3] trying to define delayed flights as something that is beyond their control [6] referring to the unanswered queries on their Facebook Fan page as something that they do in order to protect their clients' privacy and [7] diverting their clients' attention through the Low Flight Fares which have been constantly advertised on their page as observed by the researchers. Despite all the complaints regarding delayed and cancellation of flights, they are still the number one airline when it comes to low flight fare promos.

\section{F. Consistency}

The content and crisis response of the Cebu Pacific Facebook page are the factors that help in maintaining the reputation during delayed and cancelled flights. On the other hand, Communication Behavior must be improved. However, the researchers would like to argue that it just does not stop with those three factors. They should achieve another $\mathrm{C}$ factor which is Consistency. Being consistent means achieving a level of performance that does not vary over time. The customers' satisfaction is in line with consistency of the brand. (Gunelius [13], 2013). Therefore, it can be said that if Cebu Pacific has managed to reach that level of great performance on social media, they should maintain it. The researchers cogitate that if these four factors are achieved and maintained, then Cebu Pacific can increase their number of likes and further sustain their overall positive image and client support.

Thus, the researchers are proposing a simulacrum that connects all the major factors considered in this study: See Fig. 1.

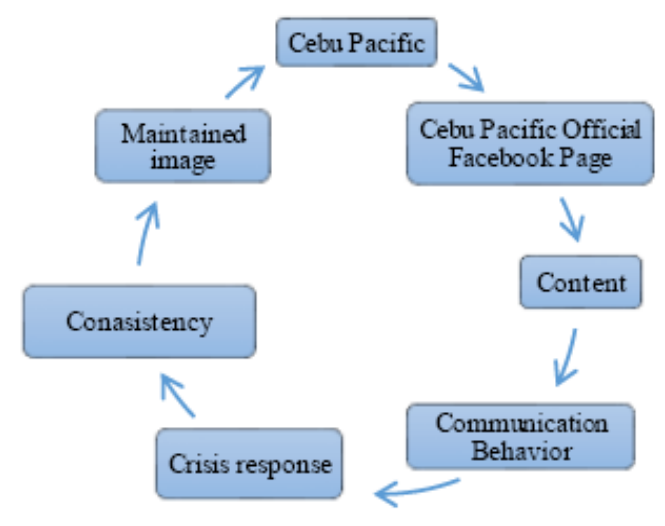

Fig. 1. In this study.

\section{CONCLUSION}

The contents of Cebu Pacific's Facebook Fan page undoubtedly contribute in maintaining the positive reputation of the airlines. With the low flight fares and promos being constantly promoted on their page, it cannot be denied that the people's attention, particularly those who have had experienced delayed and cancelled flights with Cebu Pacific, are diverted towards something that gives them a good perception of the airlines. Even though Facebook does not have a direct impact on their sales coming from the low flight fares, the constant promotion of these promos remind the clients on Facebook of something that Cebu Pacific never fails to deliver, which is the lowest flight fares in the country.

Second, the problem for Cebu Pacific when it comes to handling their page is their communication behavior. The clients have been able to pinpoint the airline's slow response time on queries concerning delayed and cancelled flights, as well as the lack of direct and concrete responses on other queries. However, frequent fliers still find the page reliable most especially in times of crisis. Even with the slow response time, the frequent fliers deem it positive in favor of Cebu Pacific once their questions or concerns have been responded to.

With this, it can be said that Facebook has been an effective tool to use for Cebu Pacific in terms of maintaining a positive perception from their clients even with all the negative posts regarding delayed and cancelled flights. The fact that even with the late replies, the clients still perceive these replies as positive means where through Facebook, these clients feel a personal and direct relationship with the company. According to Jao [14] (2013), individually responding to tweets and wall posts to let each one of the customers or prospects know that the company cares make them feel important. Conversely, since social media replies are public, when others see that 
the company responds to individual posts on social media, they'll be more engaged and be more likely to establish a relationship with your brand. And this establishment of relationship between the clients and Cebu Pacific is something that is considered positive for the company, thus maintaining a positive reputation.

With this, it can be said that Facebook has paved a way for Cebu Pacific to have favorable dealings with their frequent fliers. Cebu Pacific has also afforded their clients opportunities to become more engaged with the airlines, resulting to a good communication relationship that positively affects the reputation of Cebu Pacific.

\section{REFERENCES}

[1] X. Hua. (June 2, 2013). Cebu Pacific Plane Maes Emergency Landing in Davao. [Online]. Available: http://www.philstar.com/breakingnews/2013/06/02/949507/cebu-pacific-plane-makes-emergencylanding-davao

[2] R. Santos. (June 15,2013). Plane skids at NAIA runway. [Online]. Available:

http://www.philstar.com/headlines/2013/06/15/954150/plane-skidsnaia-runway

[3] D. Amojelar. (June 2013). Business Page. [Online]. Available: http://www.interaksyon.com

[4] J. Doorley and H. F. Garcia, Reputation Management: The Key to Successful Public Relations and Corporate Communications, $2^{\text {nd }}$ ed., 2010 Retrieved from Routledge.

[5] M. Serusi. (March 28, 2012). Simplifying. [Online]. Available: http://www.simplifying.com/2012/top-10-crisis-management-casestudies-how-social-media=can-help-airlines-deal-with-their-worstnightmares/

[6] G. Bodenlos, "Handling social media in crisis," Lodging, May 30, 2013

[7] B. Boster. (2012). 11 Shocking New Social Media Statistics in America. [Online]. Availabe: http://www.convinceandconvert.com/the-social-habit/11-shoicking new-social-media-statistics-in-america/

[8] W. Coombs, "Ongoing crisis communication: planning, managing, and responding," Sage Publications, Inc., 1993.

[9] A. Tishler and A. Carmeli. (2005). Perceived Organizational Reputation and Organization Performance: an Empirical Investigation of Industrial Eterprises. Dissertation, palgrave macmillan corporation. [Online]. Available: http://www.palgravejournals.com/crr/journal/v8/n1/abs/1540236a.html

[10] H. Worldwide. (July 19, 2013). Slow Social Response Times Prove Annoying to Millennials. [Online]. Available: http://www.marketingcharts.com/wp/ineractive/slow-social-responsetime-annoy-54-of-millenials-35176

[11] L. Stamato. (August 2008). Should business leaders apologize? Why, when and how an apology matters. Ivey Buisness Journal: Improving the Practice of Management. [Online]. Available: http://iveybusinessjournal.com/topics/leadership/should-business- leaders-apologize-why-when-and-how-an-apologymatters\#.UoljHflSg Yk

[12] T. O. Nelson, "Toward a psychology of framing effects," Political Behavior, vol. 19, no. 3, pp. 221-246. 1997.

[13] S. Gunelius. (2013). 3 Key Steps to Brand Building. How to Build a Brand and Increase Traffic to Your Blog. [Online]. Available: http://weblogs.about.com/od/marketingablog/qt/How-To-Build-ABrand-And-Increase-Traffic-To-Your-Blog-Part-1.htm

[14] J. Jao. (May 17, 2013.). 11 Personal Gestures to turn Casual Buyers into Lifelong Customers. [Online]. Available: http://www.practicalecommerce.com/articles/4011-11-PersonalGestures-to-Turn-Casual-Buyers-into-Lifelong-Customers

[15] B. Boster. (June 2013). You've earned responsible solutions, not harmfui cuts. [Online]. Available: http://www.TheHuffingtonPost

[16] M. Parkinson, Do-It-Yourself Billin Dollar Graphics, Pepper Lip, Inc., 2007.

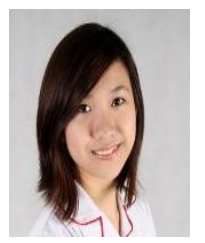

Normee Claire Noelle Agatep is a senior communication arts student of the most awarded communication school in the Philippines, Colegio de san Juan de Letran. In the future, she plans to be a PR practitioner or a lawyer.

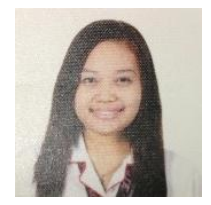

Zyra Shemitha Quierrez is a senior communication arts student of the most awarded communication school in the Philippines, Colegio de San Juan de Letran. To become a PR practitioner, particularly a Crisis Manager, or a creative script writer are her plans in the future.

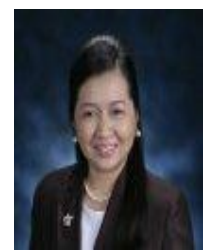

Rowena Capulong Reyes is the dean of the College of Liberal Arts and Sciences of Colegio de San Juan de Letran. She has a BA in Communication Arts from the University of Sto. Tomas, MA in Communication Management from the Asian Institute of Journalism and Communication, and a $\mathrm{PhD}$. in Development Studies from the University of Sto. Tomas. She served as the founding director of the Institute of Communication and set up four "specialist" communication programs. She holds the rank of professor, handling select communication courses; and gives lectures on leadership and personality development. Dr. Reyes research interests cover spatial governance, associational life and communication studies. An accredited PR counselor, Reyes is a partner and managing director of $5 \mathrm{BC}$ Integrated Communications. She served as chair of the 38th Metro Manila Film Festival board of jurors, and now sits as a member of the special working committee of the 39th MMFF. She is the PRO of the Philippine Association of Communication Educators, Inc., and was past president of the Public Relations Educators Association of the Philippines. 